LWSA

PAPER - OPEN ACCESS

\title{
The Argument Structure Of Halobanese (Linguistics Tipologi Study)
}

\author{
Author : Syarifuddin and Mulyadi \\ DOI $\quad: 10.32734 /$ lwsa.v3i4.1149 \\ Electronic ISSN $\quad: 2654-7066$ \\ Print ISSN : :2654-7058
}

Volume 3 Issue 4 - 2020 TALENTA Conference Series: Local Wisdom, Social, and Arts (LWSA)

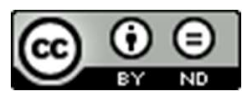

This work is licensed under a Creative Commons Attribution-NoDerivatives 4.0 International License.

Published under licence by TALENTA Publisher, Universitas Sumatera Utara

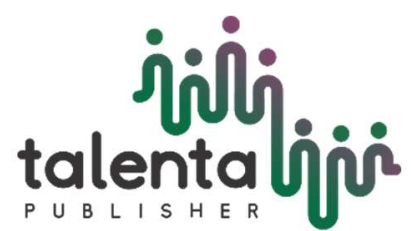




\title{
jibli

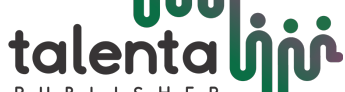 \\ LWSA Conference Series 03 (2020)

\section{The Argument Structure Of Halobanese (Linguistics Tipologi Study)}

\author{
Syarifuddin $^{\mathrm{a}}$, Mulyadi ${ }^{\mathrm{b}}$ \\ ${ }^{a}$ Balai Diklat Keagamaan Medan \\ ${ }^{b}$ Faculty of Cultural Sciences, University of Sumatera Utara, Jalan Dr. T. Mansur No. 9 Medan, 20222, Indonesia
}

aradensyarifuddin05@gmail.com, bmulyadi.usu@gmail.com

\begin{abstract}
The writing attempted to describe the argumen structure of Halobanese, Pulau Tuanku Singkil regency, Aceh. This research is a qualitative descriptive. The object of this research is the people's utterances of Haloban with data and data sources in the form of the utterances or dialogue which has been transcripted into text. Collecting data using utterances methods of simak bebas libat cakap. The interactive model data analysis is used as the data analysis in this research. The result of the research showed that argumen structures of Halobaneses are very simple. They have very limited vocabularies, phrases, clauses and sentences. They do not practice affixation in their speech.
\end{abstract}

Keywords: Argumen Structure; Halobanese

\section{Introduction}

Linguistics is the study of language. Because a language is systematic in another word it has rules and patterns so it is learnable. Therefore, linguistics is chosen as this research field. Linguistics as a science has characteristics (consistent, intact, and unambiguous), systematic (regular and patterned), and objective (structural reality). Linguistics is commonly defined as the science of language or science that takes language as the object of study.

Haloban language is one of the regional languages in Indonesia, that is, in Tuangku Island, Pulau Banyak Barat District, Aceh Singkil Regency, Aceh Province, whose speakers are also called the Haloban tribe. Judging from the social and cultural functions, according to Lasmizar, chairman of the Tuangku Island Customary Court Mahkamah Adat (MAA), The Haloban language is being used as an important role in people's lives as a means of daily communication, such as; the language of instruction in the family environment, in associations, in transactions in the market, in cultural events, and in traditional rituals, such as weddings, going to the fields, establishing and entering a new house. Apart from that, Haloban is also used in oral literature.

Each language used in the speaking community is certain to have its own uniqueness both from the point of view of the typology and the structure of the language, this is a marker of their identity, as well as the Haloban language. The Haloban language is also certain to have different characteristics from other local languages. In order to reveal these peculiarities, micro-research is needed. Furthermore, through a micro research, namely simple argumen structure, it can provide a simple description of how the Haloban language is.

Research on the argumen structure of Haloban Language needs to be done to see how the linguistic phenomenon is. Haloban language (BHL) research, until now, in micro aspect, especially the study of argumen structure, has never been carried out. The only study that has ever existed regarding BHL is by Armia (2003) in the form of a thesis. However, Armia's (2003) neither studies the typology of BHL, nor argumen structure but he only studies the syntax of BHL in general.

Historically, the notion of argumen structure is grounded in the recognition that there are no consistent semantic correlates to grammatical relations (in particular, subjects and objects). Consider the following Haloban examples, from Armia (2003):

(1) Herlin Manganke akhine

ISG A scents his younger brother

"Herlin scents his younger brother"

(2) Watu eda mahancorken jandela

INSTR smashed the window

"The rock smashed the window"

(3) Watu eda baguleng manuruni lereng

THEMA rolled down accrossed the slope

(C) 2020 The Authors. Published by TALENTA Publisher Universitas Sumatera Utara

Selection and peer-review under responsibility of International Seminar on Languages,Cultures, and History 2020

p-ISSN: 2654-7058, e-ISSN: 2654-7066, DOI: 10.32734/lwsa.v3i4.1149 
"The stone rolled down accrossed the slope".

(4) Maria maengelan Delvi balagu

EXP heard Delve singing

"Maria heard Delvi singing".

(5) Taman eda peno alek tabuan

LOC abound with wasps

"The garden abounds with wasps"

The semantic contribution made by the subject is very different in each of these sentences. In (1), it is an AGENT performing the action of 'scenting'; in (2), it represents the INSTRUMENT of an action which implies an agent; in (3), it has a relatively passive role, often referred to as THEME or OBJECT; in (4), it refers to the EXPERIENCE (as opposed to agency) of a sentient being; and in (5) it refers to a LOCATION. Despite this diversity, the syntax-semantics relationship in verbal argumen is far from arbitrary. An argumen with a THEME role can be a subject as in (3), but THEME would also appear to characterize the direct objects akhine (1) and jandela in (2), and prepositional phrase alek tabuan in (5). By contrast, in the non-subject argumen there does not seem to be any AGENT; the AGENT role is represented only by a grammatical subject, whether in combination with a finite verb in (1) or a non-finite one in (4). Thus, the object is quite variable in its semantic role, though not as much as the subject. Oblique relations, though, i.e. grammatical relations other than subject and object, are less variable in their semantic import.

Furthermore to get an idea of the argumen structure of BHL, It is proposed several similar studies related to the study that was being carried out. Other relevant research studies that already exist include (1) Tambusai (2016) "Morphological Typology and Argumen Structure in Riau Malay", (2) Wood (2012) in his research discusses "Icelandic Morphosyntax and Argumen Structure"; (3) Jufrizal (2004) in his research "Argumen Structure and Grammatical alliance of Minangkabau Language"; (4) Taoka (2000) in his research "Aspect and Argumen Structure in Japanese". The term argumen in the study of linguistic typology, especially at the syntactic level, refers to the FN element that precedes and / or follows the clause predicate. This means that the argumen is similar in meaning to the subject and / or object in a clause. In the basics of grammar theory, it is explained that (a) among the elements that build / form a sentence there is a part called the predicate (predicate) and (b) there are other elements in the sentence that act as argumens for the predicate (Jufrizal, 2012).

Alsina (1996: 4-7) said that a predicate expresses the relationship between actors in a clause. The participant is called the predicate of an argumen. Each predicate (verbal and not verbal) has a logical correspondence (relationship) with the argumens. The relationship of grammatical functions (subject), object, oblique, etc.) with predicate argumens is not random or unpredictable. Whether the argumen expressed as subject, object, etc, is determined in part by the semantics of the predicate. Each verb must correspond to the argumen. The entanglement and information linkages that become the predicate and predicate argumens themselves form a structure, which is called the argumen structure. Argumen structure is also the minimum information necessary for the predicate to derive its syntax framework.

Azhari (2016: 67), refers to Manning's opinion (1996: 35- 36), argumen structure is seen more as a semantic rather than syntactic manifestation. Manning places the problem of the argumen structure as the embodiment of syntax. Further more the grammatical structure and the argumen structure are the direct result of grammaticalization of two different sets of relationships. The grammatical structure is the result of grammaticalization of the roles of discourse (discourse) while the argumen structure is the result of grammaticalization of semantic prominence thought.

The aims of this study is to analyze and to explain the structure argumen of BHL. BHL was chosen as the linguistics study because the writer wanted to document this language. To get a maximum target for this discussion, there are some items of BHL that will be discussed, i,e; the basic structure of the clause, the word order typology, the argumen structure and the grammatical behavior of the subject, object, and oblique, the properties of the agent and the patient, as well as the structure of compound clauses and equivalent clauses of multi-layered BHL Many jobs who are particularly productive in the structure of argumen focused on 'succession'; the case where a verb appears compatible with more than one argumen structure. One line of work, represented by Levin (1993), aims to classify semantically independent root verbs in order to find out which substitution the semantic class follows. It turns out, however, that this kind of semantic classification can only partially predict changes in the structure of the argumen. For almost every class of verbs in Levin (1993), one can find a verb that is different from other class members not easily (Wood, 2012).

An opinion similar to Wood's above was also presented by Croft (2010) that the construction of argumen structures is more complex and controversial. The construction symbolizes the role of participation with events symbolized by the case marker prediction of the argumen phrase, indexation (agreement with) the argumen phrase used for this purpose, the word order of the argumen, the phrase in a simple declarative clause. 


\section{Method}

Method is an aspect that has a big influence and is very important on the results of a study. The research method is a scientific approach or method that is carried out to obtain data with a specific purpose. The method used in this research is descriptive method. According to Moleong (2014: 11) the descriptive method is data collected in the form of words, pictures, and not numbers. In line with the opinion of Nawawi and Moleong, Nazir (Darmadi, 2014: 185) this descriptive method can also be interpreted as a method of examining the status of a group of humans, an object or a class of events in the present which aims to systematically create descriptions, drawings or paintings., factual, and accurate regarding the facts, characteristics and relationships between the phenomena being investigated. Descriptive method is considered in accordance with this research because this study aims to describe and provide an objective description of the form and meaning of BHL.

This type of research is descriptive qualitative. Qualitative descriptive research is research that aims to make descriptions, create pictures, paint systematically, factually and accurately about the data, characteristics and relationships of the phenomena under study. The choice of descriptive research type in language research tends to be used mainly in collecting data and describing data scientifically (Djajasudarma, 2006: 9). Data is the material for research (Sudaryanto, 1990: 66).

The data of this research is the spoken language spoken verbally by the Haloban community, both within the family environment and in the community environment in Pulau Tuangku, Haloban village and Asantola village, Pulau Banyak Barat subdistrict, Singkil district, Aceh province. Data collection used recording techniques and note-taking techniques (Sudaryanto, 1992: 33). Maman and Sambas (2011: 74) say that data is all facts or information about something that can be used as material to compile information. According to Darmadi (2014: 33) data are empirical facts collected by researchers for the benefit of solving problems or answering research questions. Arikunto (2013: 161) explains that data is the result of the researcher's record, either in the form of facts or figures. This research data is in the form of oral data.

The data analysis techniques in this study were direct observation techniques, engaging listening techniques and unstructured interviews. The data collection tools in this study were field notes, tape recorders, and cameras. In addition to data collection techniques and tools, researchers also used data validity techniques in the form of triangulation of sources and peer examination through discussion. Furthermore, the last step that the researchers took was analyzing the data. The data analysis technique used in this study was the interactive model data analysis technique of Miles and Huberman (Sugiyono, 2014: 92). Analysis of the results of the data carried out in this study together with the process of data collection, data reduction, data presentation and finally drawing conclusions / data verification.

The presentation of the results of data analysis in this study was carried out using informal and formal methods. The informal presentation is in the form of a formula using ordinary words, while the formal presentation is a formulation with signs and symbols (Sudaryanto, 1993: 145). Likewise according to Mahsun (2005: 123) that the informal method is a formulation using technical terminology, and the formal method is a formulation using signs or symbols.

This is a descriptive research. It means a description of the symptoms or conditions that occur in the research data. Presenting the results of the analysis is used informal and formal methods. The use of these two methods is because in addition to the presentation it is carried out using ordinary words also by using signs and symbols.

\section{Result And Discussion}

\subsection{Basic Structure of the BHL Clause}

A clause is a syntactic construction that contains elements of predication. The basic clause has characteristics such as (1) consisting of one clause (2) the core elements are complete (3) the arrangement of the elements according to the most common and (4) does not contain questions or denials (Alwi, et al: 2000). Agent and patient are the two most important things in the study of the argumen structure.

BHL has basic verbal clauses and basic non-verbal clauses. Verbal clauses are clauses whose predicate is verbs, while nonverbal clauses are clauses whose predicate are nouns, numeralia, prepositional, adjectival, for example;

(6) Anak eda menggek. ( $\mathrm{p}=$ Verb)

'The child is crying'

(7) Apak o guru. $(\mathrm{p}=$ noun $)$

'My father is a teacher'

(8) Akhine raro. $(\mathrm{p}=$ Numeralia $)$

'Little brother two'

(9) Mak mek pasa. $(\mathrm{p}=$ prepositional)

'Mom to the market'

(10) Ata eda makhurut manti. ( $\mathrm{p}+$ Adjective) 
'That person is so thin'

In example (6) the subject of the clause is Anak eda "that child" and the predicate is verbalizing. In example (7) Apak o is the subject and the word teacher (nominal) is the predicate. In example (8) Akhine is the subject and predicts the word raro (numeralia). In example (9) Mak is the subject and mek pasa (prepositional phrase) serves as a predicate. In example (10) Ata eda is the subject and makhurut manti (adjectival phrase) serves as a predicate.

Next, in the Haloban language system there are some verbal clauses where its free morphemes are already verb and some are accompanied by affixation. The presence of affixation becomes the reason to change the morphemes to become verbs. To express something, it is enough for the BHL speakers to organize existing basic vocabulary. For them, the principle in communicating is the transfer of messages not more than that. When the message conveyed can be captured by the interlocutor, the work of both the speaker and the interlocutor is considered complete.

(11) Mak o mangawangi luma deo.

"My mother perfumed our house".

(12) Apak Weteng mengantet ek luan.

"Dad is fishing in the river".

The clause argumen structure above is very simple. In data 11 the lexicon mang- + awangi = mangawangi "scent" the real meaning is to give fragrance to. The category keep "fragrant" adjective turned into a verb. Likewise, in the data 12 the mengantet lexicon actually means fishing. The presence or unpresence of the affixes in verbs as in data 11 and 12 does not affect the basic structure of the clause. The basic structure of the clause consists of a subject, prediket, object and description. Furthermore, in data (11) Mak o and data (12) Apak as an actor who takes action. Mak o does the act of giving perfume to the house, while Apak does the act of fishing. An actor is an argumen from a predicate which states that the participant does, influences, instigates, or controls the action situation shown through the verb (Foley and Van Valin, 1984: 29). Thus, it can be argued that actors have an important role in deliberately carrying out an action. Actor is the cause of an event.

\subsection{2 Transitive Clause}

Transitive clauses are clauses that contain transitive verbs, i,e verbs that have the capacity to have one or more objects. This is related to (Tarigan, 1986: 38) that a transitive clause is a clause that contains a transitive verb, which is a verb that has the capacity for one or more objects.

Example;

(13) Mamak mangareen wokge eda

"Uncle fixed the boat".

(14) Apakne mameli khapal sewalu

"His father bought a new ship"

(15) Mak o mengawan wakdu eda

"My mother sells the clothes"

The data (13), (14) and (15) presented contain verbs that require an object. The verbs mangareen, mameli, mangawan which are stated in the data above are transitive verbs followed by the following words that complement the meaning of the sentence. If the object is omitted, the sentence's intent is incomplete. For example;

(16) Dise mengawan

"He's selling"

(17) Tukang eda Malang

"The craftsman nails"

(18) Patani eda manawe

"The farmer is cutting down"

(19) Satiok walal patani eda makhawali

"Every day the farmer is looking for"

The data (16) through (19) are sentences that have no complementary element or object after the transitive verb that is present in the sentence. The resulting sentence is not grammatical because the argumen structure is incomplete. In other words, the verb requires other elements to complete the meaning of the sentence. The necessary elements are described in examples (16) to (19) above. 
In practicing, BHL speakers also understand that if a sentence is not completed by any objects, it is not attached, the meaning of the sentence is imperfect, and the communication does not achieve the results. This principle of communication can be seen in everyday conversations, except for interrogative sentences which typify a few words before or after the main word because it is assumed that the listener has understood the meaning of the sentence. For example: mae !, 'go'! mantaeng! 'sit down!', Sumenneng! 'Silence!.

\section{Conclusion}

The argumen structure of BHL has its own unique. In speaking, BHL's speakers do not use a complex expressions as other regional languages speakers consisting of subject, predictions, objects and descriptions, but they are simpler and not convoluted. They rarely use affixation, but they tend to take advantage of the role of actors who often change functions. They only process the words they have into sentences. They themselves made no effort to develop their language. They are more passive, meaning they never think about the future fate of their language. The existence of casual workers is still maintained because their parents and their communities still use them in their daily lives.

\section{References}

[1] Alsina, A. 1996. The Role of Argumen Structure in Grammar. Evidence from Romance. California: CSLI.

[2] Chiaka Taoka. 2000. Aspect and Argumen Structure in Japanese. Disertasi. Tokyo: Department of Linguistics University of Manchester.

[3] Croft, William. 1993. Typology and Universals. Cambridge: Cambridge University.

[4] Dahlan, Saidat dkk. 1985. Pemetaan Bahasa daerah Riau dan Jambi. Jakarta: Pusat Pembinaan dan Pengembangan Bahasa Departemen Pendidikan dan Kebudayaan.

[5] Djajasudarma. 2006. Metode Linguistik Ancangan Metode Penelitian dan Kajian. Bandung: PT. Eresco.

[6] Foley, William A dan Robert D. Van Valin. 1984. Fungsional Syntax and Universal Grammar.Cambridge: Cambridge University Press.

[7] Hasan, dkk. 1983. Morfologi dan Sintaksis Bahasa Melayu Riau. Jakarta: Pusat Pembinaan dan Pengembangan Bahasa Departemen Pendidikan dan Kebudayaan.

[8] Jufrizal. 2004. "Struktur Argumen dan Aliansi Gramatikal Bahasa Minangkabau” Disertasi”. Denpasar Program Doktor (S3) Linguistik Universitas Udayana.

[9] Jufrizal. 2012. Tatabahasa Minangkabau: Deskripsi dan Telaah Tipologi Linguistik. Padang: UNP Press.

[10] Levin, Beth. 1993. English Verb Classes and Alternations. Chicago: The University of Chicago Press. Lockwood,W.B. 1955.

[11] Mahsun. 2005. Metode Penelitian Bahasa: Tahapan Strategi, Metode, dan Tekniknya. Jakarta: Raja Grafindo Persada.

[12] Manning, C.D. 1996. Ergativity: Argumen Structure and Gramatical Relations. California: CSLI.

[13] Sudaryanto. 1992. Metode dan Aneka Teknik Analisis Bahasa. Yogyakarta: Duta Wacana University Press.

[14] Tambusai Azhary. 2016. "Tipologi Morfologis dan Struktur Argumen Bahasa Melayu Riau”. Disertasi. Medan USU.

[15] Tarigan H.G. 1986. Prinsip-prinsip Dasar Sintaksis. Bandung: Angkasa.

[16] Wood, Jim. 2012. Icelandic Morphosyntax and Argumen Structure. New York University: Department of Linguistics. 